\title{
Gonadotropin-releasing hormone and the control of gonadotrope function
}

\author{
Raymond COUNIS ${ }^{\mathrm{a} *}$, Jean-Noël LAVERRIÈRE ${ }^{\mathrm{a}}$, Ghislaine GARREL ${ }^{\mathrm{a}}$, \\ Christian BLEUX ${ }^{\mathrm{a}}$, Joëlle COHEN-TANNOUDJI ${ }^{\mathrm{a}}$, Yannick LERRANT ${ }^{\mathrm{b}}$, \\ Marie-Laure KOTTLER ${ }^{\mathrm{c}}$, Solange MAGRE ${ }^{\mathrm{a}}$
}

\author{
a Physiologie de l'axe gonadotrope, UMR-CNRS 7079, Université Pierre et Marie Curie, Paris, France \\ b Université de la Nouvelle Calédonie, Nouméa, Nouvelle Calédonie \\ ${ }^{\mathrm{c}}$ Département de génétique et reproduction, CHU de Caen, Caen, France
}

\begin{abstract}
Normal gametogenesis and steroidogenesis is highly dependent on the pulsatile release of hypothalamic GnRH that binds high-affinity receptors present at the surface of pituitary gonadotrophs thereby triggering the synthesis and release of the gonadotropins LH and FSH. The mammalian $\mathrm{GnRH}$ receptor displays the classical heptahelical structure of $\mathrm{G}$ protein-coupled receptors with, however, a unique feature, the lack of a C-terminal tail. Accordingly, it does not desensitise sensu stricto, and internalises very poorly. It is now well established that GnRH stimulation induces the activation of a complex network of transduction pathways involved in the control of gonadotropin release and subunit gene expression. Other authors and ourselves have demonstrated that the GnRH action is associated with an increased complexity regarding gene regulation/cell function. Indeed GnRH affects the GnRH receptor gene itself and a number of additional genes that include some involved in cell signalling and auto-/paracrine regulation. The fact that GnRH regulates the expression of its own receptor, together with a host of other genes typically involved in its signal transduction cascades implies alteration/auto-adaptation in gonadotropic responsiveness. Furthermore, some of these genes respond differentially depending on whether the GnRH stimulation is intermittent or permanent suggesting specific roles in the dual process of activation/desensitisation. Thus, it can be assumed that the importance of pulsatility of GnRH action is closely related to, or dependent on, the inability of the GnRH receptor to desensitise. Moreover, multiple post-receptor events are crucial for both the regulation/plasticity of gonadotropic function and the maintenance of cell integrity.
\end{abstract}

GnRH receptor / signalling / gene regulation / transcription factor / gonadotropins / secretion

\section{INTRODUCTION}

The hypothalamic gonadotropin-releasing hormone pGlu-His-Trp-Ser-Tyr-Gly-LeuArg-Pro-Gly- $\mathrm{NH}_{2}$ known as mammalian GnRH or GnRH I plays a key regulatory role in the neurohormonal control of repro- duction by stimulating the release of the pituitary gonadotropins LH and FSH. The pulsatile neuronal delivery of $\mathrm{GnRH}$, itself centrally regulated in amplitude and frequency, is essential for maintaining the serum gonadotropin profiles required for normal steroidogenesis and gametogenesis.

\footnotetext{
* Corresponding author: Raymond.counis@snv.jussieu.fr
} 
Whereas physiological fluctuations in $\mathrm{GnRH}$ orchestrate normal reproduction, high levels or prolonged stimulation lead to the suppression of gonadotropin secretion. This dual response has made the GnRH receptor a target for short- or long-term treatments with $\mathrm{GnRH}$ analogues in a wide range of human or animal applications such as reproduction/fertility, steroid/growth-related dysfunction or sex steroid-dependent cancer $[1,2]$. The mechanisms by which GnRH could regulate the secretion of two gonadotropins, notably in some instances in a coordinate or differential manner, have been the subject of ongoing intensive investigation. Over the past 25 years, molecular biology, and more recently imaging and transgenic techniques have been used extensively, providing a substantial amount of novel information. In mammals, GnRH was shown to operate via an atypical $\mathrm{G}$ protein-coupled receptor and to regulate cellular function by affecting the activity of a growing number of genes, some of which would modulate its functional impact in relation with the stimulation mode.

\section{GnRH AND PITUITARY GONADOTROPIN SECRETION}

The fundamental function of GnRH, which led to the initial peptide isolation, was the induction of the release of pituitary gonadotropins. Nevertheless, the question of whether GnRH alone or in combination with other hormones/factors may also regulate the synthesis of LH and FSH was addressed very early. As described below, the biosynthesis and release of these hormones occur in the context of a complex secretory mechanism and the two processes are thus closely interconnected.

\subsection{Structure and biosynthesis of pituitary gonadotropins}

LH and FSH belong to a family of structurally related glycoprotein hormones that include the pituitary thyrotropin TSH and, in certain species such as primates and equids, the placental choriogonadotropin CG [3]. All these hormones are composed of two distinct, noncovalently associated glycosylated subunits, a common $\alpha$ - and a specific $\beta$-subunit. Cell-free translation studies and molecular cloning, have demonstrated that each subunit is synthesised as a precursor with a signal peptide preceding the authentic subunit sequence and these precursors are encoded by distinct mRNA transcribed from separate genes (Tab. I). LH and FSH, i.e. subunits $\alpha, \mathrm{LH} \beta$ and FSH $\beta$ are expressed within the same cells although mono- and bihormonal gonadotrophs coexist [4]. Precursor cleavage and first steps of $\mathrm{N}$-glycosylation occur cotranslationally as the nascent proteins enter the endoplasmic reticulum, allowing early association into immature $\alpha / \beta$ heterodimers. The completion of a functional $\mathrm{LH}$ or FSH then takes place during migration along the Golgi apparatus resulting in the progressive acquisition of a specific mature glycosylation and conformation, and an ultimate achievement within the secretory granules $[4,5]$. The synthesis of gonadotropins thus follows the general pathway of secreted proteins in eukaryotes with, however, some distinct features concerning essentially heterodimerisation, sugar type $\mathrm{N}$-glycosylation and sorting in separate granules. Although this biosynthetic system has the potential for a number of control points this review will concentrate essentially on the gene expression level.

\subsection{GnRH control of gonadotropin secretion}

\subsubsection{Importance of the GnRH I system in mammals}

While GnRH was initially isolated and characterised by its ability to induce the release of pituitary gonadotropins, an array of evidence initially argued in favour of an indispensable role for GnRH in promoting gonadotropin gene expression. Indeed, it has been known for a long time that a genetic defect in GnRH I secretion in 
Table I. Major characteristics of the human and rat gonadotropin subunit genes, mRNA transcripts and precursors.

\begin{tabular}{|c|c|c|c|c|c|c|c|c|}
\hline & $\begin{array}{c}\text { Chromosome } \\
\text { assignment }\end{array}$ & $\begin{array}{c}\text { Transcription } \\
\text { unit } \\
(\mathrm{kb})\end{array}$ & $\begin{array}{l}\text { Number of } \\
\text { Exons }\end{array}$ & $\begin{array}{c}\text { mRNA } \\
(\mathrm{kb})^{\mathrm{a}}\end{array}$ & $\begin{array}{l}\text { Signal } \\
\text { peptide } \\
\text { (aa) }\end{array}$ & $\begin{array}{c}\text { Subunit } \\
\text { (aa) }\end{array}$ & $\begin{array}{c}\text { S-S } \\
\text { bonds }\end{array}$ & $\mathrm{CHO}^{\mathrm{b}}$ \\
\hline hu $\alpha \mathrm{GSU}$ & $6(q 12-q 21)$ & 9 & 4 & 0.8 & 24 & 92 & 5 & 2 \\
\hline rat $\alpha \mathrm{GSU}$ & $5(q 13-q 24)$ & 8 & 4 & 0.8 & 24 & 96 & 5 & 2 \\
\hline hu LH $\beta$ & $19(\mathrm{q} 13.32)$ & 1.4 & 3 & $\sim 0.7$ & 20 & 121 & 6 & 1 \\
\hline rat $\mathrm{LH} \beta$ & 1 (q22) & 1.1 & 3 & $\sim 0.7$ & 20 & 121 & 6 & 1 \\
\hline hu $C G \beta^{c}$ & $19(\mathrm{q} 13.32)$ & (cluster) & 3 & 1 & 20 & 145 & 6 & 2 \\
\hline hu FSH $\beta$ & $11(\mathrm{p} 13)$ & 3.9 & 3 & 1.7 & 19 & 110 & 6 & 2 \\
\hline rat FSH $\beta$ & 3 (q33) & 3.1 & 3 & 1.7 & 19 & 110 & 6 & 2 \\
\hline
\end{tabular}

a Includes the poly(A+) sequence.

b $\mathrm{CHO}$ : asparagine-linked carbohydrate chains.

c No CG $\beta$ gene in the rat

hu, human; aa, amino acids.

rodents [6] and humans [7, 8] results in a substantial decrease in serum gonadotropins associated with hypogonadism, impuberism and infertility. The same phenotype was observed more recently in patients with loss of function mutations in the GnRH type I receptor gene [9]. Such mutation-induced dysfunctions are consistent with a similar substantial depression in serum $\mathrm{LH}$ and FSH observed in response to experimental disruption of the $\mathrm{GnRH} / \mathrm{GnRH}$ receptor system, which result from endogenous GnRH immunoneutralisation, surgical hypothalamus-pituitary disconnection or an antagonist-mediated GnRH receptor blockade [10, 11]. In all cases, a low expression of all three gonadotropin subunit genes $\alpha, \operatorname{LH} \beta$ and FSH $\beta$ was confirmed via measurement of pituitary mRNA content. In spite of the possible expression of more than one GnRH variant in a given species, and notably of GnRH II (pGlu-His-Trp-Ser-His-GlyTrp-Tyr-Pro-Gly-NH${ }_{2}$ ) in humans [12], the above data demonstrated the crucial importance of the GnRH I system in the control of gonadotropin expression and consequently, of the pituitary gonadotropic function. Accordingly, only reference to GnRH I will be made further in this review, under the usual generic term GnRH.

\subsubsection{GnRH is crucial for regulated expression of gonadotropin subunit genes}

A number of investigations have demonstrated that GnRH stimulates in vitro the synthesis of gonadotropin subunits and increases $\alpha, \mathrm{LH} \beta$ and FSH $\beta$ subunit mRNA levels as well as the transcriptional activity of corresponding gene promoters. Taking into account its crucial importance on gonadotropin release, the effect of GnRH pulse frequency and/or amplitude on gonadotropin subunit gene expression was evaluated. Several in vitro and in vivo models such as anterior pituitary cell cultures or animals with surgical or pharmacological hypothalamus-pituitary disconnection were used to demonstrate that the individual gonadotropin genes responded differentially to the frequency of GnRH pulses. Indeed, low frequencies in the range one stimulus every two or four hours appear to preferentially increase FSH $\beta$ mRNA levels whereas higher frequencies preferentially stimulate $\mathrm{LH} \beta$ and $\alpha$ subunit mRNA [13, 14]. In vivo, permanent exposure to $\mathrm{GnRH}$ leads to a more or less rapid depletion of both $\mathrm{FSH} \beta$ and LH $\beta$ mRNA in a manner that suggests a rapid transcription arrest followed by RNA degradation, while the $\alpha$-subunit mRNA 
remains constant or increases only slightly for days [15-17]. The latter data are consistent with current clinical studies showing that long-term administration of GnRH superagonists induces depletion of $\mathrm{LH}$ and $\mathrm{FSH}$ but increases free $\alpha$-subunit levels in the serum of treated patients [18].

Collectively these data suggest the presence of some specific mechanisms that differentially regulate the expression of three genes within a single cell. These may involve GnRH receptor signalling, mRNA stability and/or subunit gene promoter properties. Alternatively, an indirect modulation by factors such as steroids or members of the transforming growth factor- $\beta$ superfamily i.e. activins, bone morphogenetic proteins (BMPs) and inhibins, has also been suggested. Indeed, the latter three types of substances as well as follistatin, a polypeptide which binds and functionally incapacitates activins and BMPs, are specific regulators of FSH and, in the absence of a specific FSH-releasing factor, may explain instances in which FSH and LH secretion diverge. The fact that these factors are produced in the anterior pituitary support the potential for a paracrine/autocrine regulation. The mechanism of action of such factors in conjunction with GnRH is, however, unclear. Moreover, increasing the degree of complexity of the regulatory system, GnRH appears to function through interaction with a particular unusual receptor.

\section{STRUCTURE AND FUNCTIONAL PROPERTIES OF THE GnRH RECEPTOR}

\subsection{The peculiar structure of mammalian GnRH receptor}

It was suggested by the mid 1980s [19] that the GnRH receptor belonged to the family of G protein-coupled receptors (GPCR). However, it was only after 1992 that the cloning of cDNA from various species and the deduced amino acid sequences confirmed that the GnRH receptor possessed the typical structural features of this super- family. These include the seven membrane spanning $\alpha$-helices, which contribute to the conformation of the ligand-binding pocket, connected to three intracellular and three extracellular loops functionally crucial for ligand binding and signal transduction, respectively [20]. The most striking structural feature of the mammalian $\mathrm{GnRH}$ receptor is the lack of a cytoplasmic C-terminal tail. This terminal extension present in all classical GPCR is the target for GPCR kinases and the consequent phosphorylation-mediated $\beta$-arrestin binding that results in the endocytic processing of the receptorligand complex via clathrin-coated pits [21, 22]. Interestingly, the non-mammalian $\mathrm{GnRH}$ receptors that were discovered later do exhibit a C-terminal tail structurally and functionally similar to that of other members of the GPCR family [20, 23]. Therefore, in contrast to the latter receptors, the mammalian GnRH receptor does not desensitise and internalises poorly [24-26]).

Such pecular properties, which suggest genetic/functional evolutionary adaptation in relation with the pulsatile character of GnRH secretion, imply that the so-called "desensitisation" i.e. the loss of a releasing response to GnRH, does not result from proper receptor inactivation/recycling as is common to all GPCR but rather from postreceptor mechanisms. In this respect, another important implication for cell function is the possibility that $\mathrm{GnRH}$, depending on the frequency and the time of action may exert a selective activation or inactivation on specific intracellular processes.

\subsection{GnRH receptor signalling}

It has long been established that the GnRH receptor preponderantly coupled with $\mathrm{G} \alpha \mathrm{q} / \mathrm{G} \alpha 11$ activates phospholipase $\mathrm{C}$ (PLC, $\beta$ isoform) resulting in the formation of diacylglycerols and inositol-trisphosphate (IP3). These latter two second messengers are responsible for the activation of several protein kinase $\mathrm{C}$ ( $\mathrm{PKC}$ ) isoforms and the mobilisation of intracellular $\mathrm{Ca}^{2+}$, respectively. This process together with the 
massive entry of $\mathrm{Ca}^{2+}$ that occurs through voltage-dependent or -independent channels [27] is primarily involved in acute gonadotropin release. GnRH can also induce the activation of the mitogen associated protein kinase (MAPK) cascade through PKC to stimulate the expression of gonadotropin subunit genes [28, 29]. Elevation of intracellular $\mathrm{Ca}^{2+}$ also activates the NO synthase (NOS I) cascade (NOS I/NO/soluble guanylate cyclase) that results in the rapid production of cGMP [30,31], providing another example of an indirectly activated signalling pathway. GnRH can also induce phospholipases D and A2, as well as a delayed production of cAMP however, the mechanisms involved remain obscure. Cyclic AMP has been shown to be capable of inducing increased expression of $\mathrm{LH}$ subunit genes and the release of newly synthesised LH $[32,33]$ as well as an increased expression of the GnRH receptor [34] and NOS I [35, 36] genes.

Sustained activation of the PKC is followed by proteasome mediated degradation of certain isoforms, a process that may be involved, at least in part, in the desensitisation of GnRH-induced cellular responses [37]. A similar GnRH-induced degradation of IP3 receptors has also been described [38]. In addition to such metabolic events, studies have shown that GnRH may also alter the degree of its effect on gonadotropin secretion through its multigenic regulatory action within the gonadotrophs.

\section{ACTIVATION OF THE GnRH RECEPTOR MODULATES ACTIVITY OF A LARGE NUMBER OF GENES: POTENTIAL FOR SUBTLE, FINE-TUNE CONTROL OF GONADOTROPIN SECRETION}

\subsection{The multigenic impact of GnRH stimulation}

Previously a few genes, in the range of 10-20, have been shown to be regulated by
GnRH using various conventional investigations. More recently, microarray analyses have increased the number of these genes to over 200 [39]. To date, however, much more is known from the first approach. Interestingly, excluding the three gonadotropin subunit genes, GnRH regulates genes essentially associated with the signalling network such as the GnRH receptor itself $[17,40]$, NOS I [41], or PKA and PKC subunit isoforms [42, 43] as well as transcription factors such as cFos, cJun or Egr-1. Regulation of the GnRH receptor gene followed a similar extreme dependency on the mode of GnRH stimulation previously revealed for the gonadodotropin $\beta$-subunit genes $[17,40]$. For both the GnRH receptor and the NOS I genes, evidence exists that the expression is up-regulated at proestrus of the ovarian cycle $[31,44,45]$ suggesting a functional adaptation of the signalling machinery at this important physiological stage. GnRH receptor and NOS I promoters have been isolated and studies have characterised their tissue-specific and regulated expression in vitro using a transient transfection assay [36, 46-51] and/or in vivo using transgenesis [52-54]. In each case and regardless of their degree of characterisation, promoters appear to require a specific combination of transcription factors to achieve both tissue-specific and regulated gene expression as illustrated for the $\mathrm{GnRH}$ receptor gene in Figure 1. It is noteworthy that combinations of transcription factors share several elements in common with those of the gonadotropin subunit genes. In these combinations, the orphan nuclear receptor, steroidogenic factor 1 (SF-1), might be considered as the most critical since it has been shown to be involved in the tissue-specific expression of the mouse, rat and human GnRH receptor gene as well as in the expression of the alpha, LH $\beta$ and FSH $\beta$ subunit genes (Tab. II).

Like gonadotropin subunits, the availability of tissue-specific promoters for the GnRH receptor and NOS I genes shows that GnRH itself operates through stimulation of transcriptional activity. Domains involved 

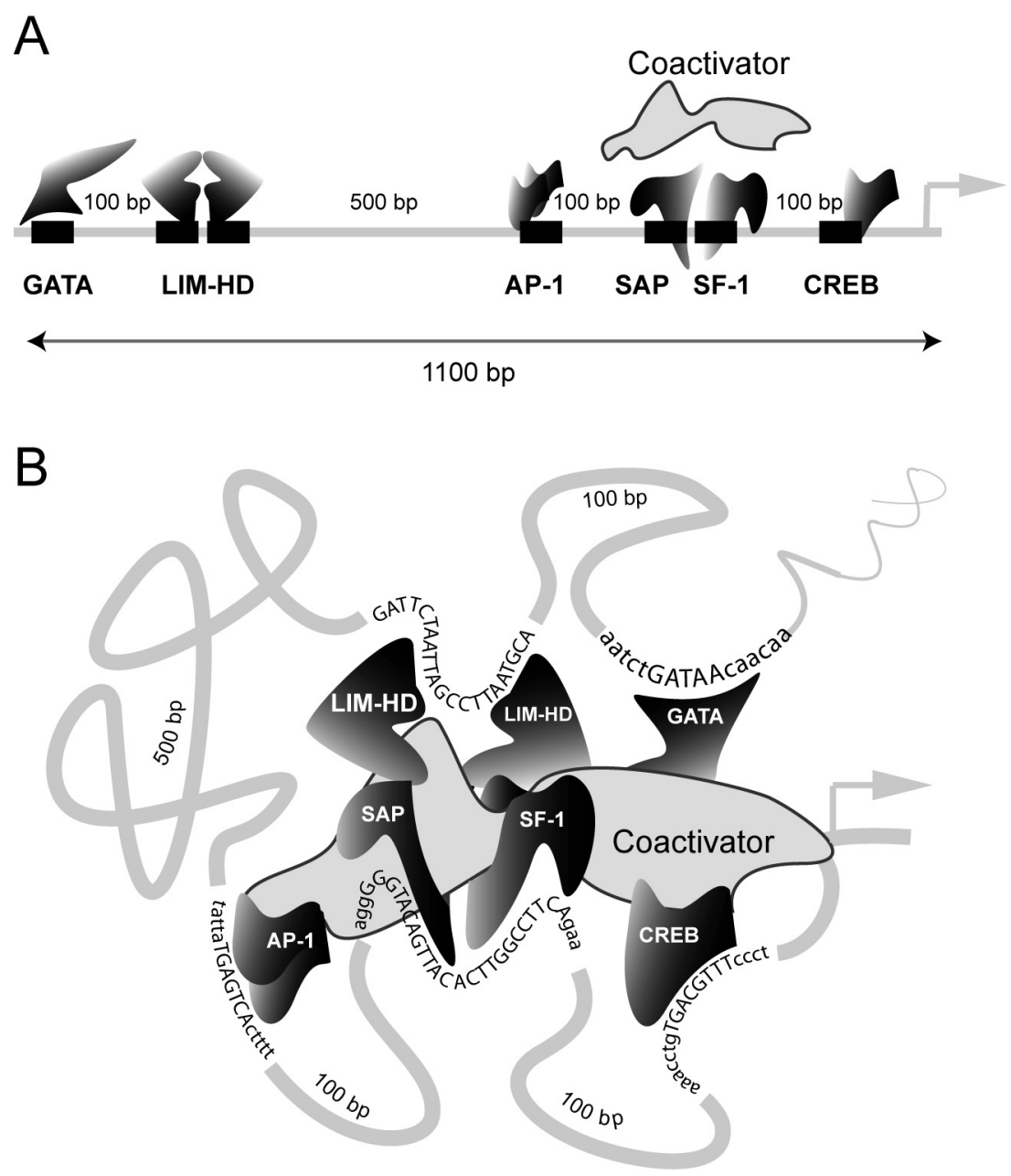

Figure 1. Gonadotrope-specific elements within the promoter of the rat GnRH receptor gene. (A) Linear representation of the elements identified in the proximal domain (AP-1, SAP, SF-1 and CREB) and in the distal enhancer (GATA, LIM-HD). The proximal elements act cooperatively, most probably by recruiting a coactivator as yet unidentified. The distal enhancer is functionally and, at least for a part, physically linked to a couple of motifs in the proximal domain that bind SAP and SF-1. (B) Speculative representation of the promoter taking into account the functional and physical interactions that were recently established with regards to SF-1 and the LIM-HD factors of the distal enhancer ([49] and Granger et al., manuscript in preparation). Similar interactions most likely occur between SF-1 and GATA as well as between SAP, LIM-HD and GATA factors. The coactivator may facilitate interactions between distal and proximal domains of the promoter. The motifs identified by linker-scanning mutagenesis for each factor are indicated with their approximate interval distances in base-pairs (bp). GATA; GATA-related factor, LIM-HD; LIM homeodomain proteins, AP-1; activating protein 1, SAP; SF-1 associated factor (unidentified), SF-1; steroidogenic factor 1, CREB; cAMP response element binding protein. 
Table II. Transcriptional factors shared in the combinatorial codes of GnRH regulated genes in the pituitary gonadotrophs.

\begin{tabular}{|c|c|c|c|c|c|c|c|}
\hline & Pitx1-RE & GATA & LIM-HD-REa & SF-1/GSE & CRE & Sp1 & AP-1 \\
\hline \multicolumn{8}{|l|}{$\overline{\alpha \mathrm{GSU}}$} \\
\hline human & $-80 /-65$ & $-161 /-141$ & $-329 /-320$ & $-220 /-211$ & $-146 /-111$ & & \\
\hline murine & $-398 /-385$ & - & $-344 /-300$ & $-220 /-202$ & $-144 /-126$ & & \\
\hline \multicolumn{8}{|l|}{ LH $\beta$} \\
\hline rat & $-99 /-96$ & & & $-58 /-51$ & & $-366 /-354$ & \\
\hline & & & & $-127 /-119$ & & $-450 /-434$ & \\
\hline bovine & $-100 /-95$ & & & $\begin{array}{c}-59 /-52 \\
-128 /-121\end{array}$ & & & \\
\hline \multicolumn{8}{|l|}{ FSH $\beta$} \\
\hline $\begin{array}{r}\text { rat } \\
\text { porcine }\end{array}$ & $-54 /-49$ & & $\begin{array}{c}- \\
-219 /-209\end{array}$ & & & & \\
\hline & - & & $\begin{array}{c}-259 /-253 \\
-295 /-284 \\
-838 / 809 \\
-1442 /-1423 \\
-5057 /-5030\end{array}$ & & & & \\
\hline murine & - & & - & $\begin{array}{l}-341 /-333^{b} \\
-239 /-231^{b}\end{array}$ & & & $-72 /-69^{c}$ \\
\hline \multicolumn{8}{|l|}{ GnRH rec } \\
\hline $\begin{array}{r}\text { rat } \\
\text { murine }\end{array}$ & $\begin{array}{c}- \\
-370 /-326^{\mathrm{d}}\end{array}$ & $\begin{array}{c}-983 /-962^{\mathrm{d}} \\
-\end{array}$ & $\begin{array}{c}-871 /-859^{d} \\
-\end{array}$ & $\begin{array}{l}-245 /-237^{\mathrm{d}} \\
-243 /-235^{\mathrm{d}}\end{array}$ & $\begin{array}{l}-110 /-104^{\mathrm{d}} \\
-109 /-102^{\mathrm{d}}\end{array}$ & & $\begin{array}{l}-352 /-346^{\mathrm{d}} \\
-336 /-330^{\mathrm{d}}\end{array}$ \\
\hline \multicolumn{8}{|c|}{ NOS I } \\
\hline $\begin{array}{r}\text { rat } \\
\text { murine }\end{array}$ & & & $-62 /-55^{f}$ & $-206 /-298^{\mathrm{g}}$ & $-4 /+4^{f}$ & $-66 /-57^{\mathrm{f}}$ & \\
\hline
\end{tabular}

The presence of only clearly demonstrated functional sites is indicated in bp. In the absence of specific indications, numbering is expressed with reference to initiation of transcription. Pitx1-RE, pituitary homeobox 1-responsive element; LIM-HD-RE, LIM homeodomain-responsive element; SF-1, Steroidogenic factor 1; GSE, gonadotrope specific element; Sp1, Specific protein 1; AP-1, Activating protein 1.

${ }^{\text {a }}$ Corresponds to PGBE (pituitary glycoprotein hormone basal element).

$\mathrm{b}$ Function in interaction with nuclear factor $\mathrm{Y}$.

c Half-site.

${ }^{\mathrm{d}}$ Numbering relative to ATG translation start site where A is at position +1 .

e Unpublished data from our laboratory.

${ }^{\mathrm{f}}$ Numbering relative to exon 1a transcription start site (major promoter resides in exon 1a).

g Numbering relative to exon 2 translation start site (major promoter resides in exon 2).

in the GnRH response have been localised and in some cases identified [36, 47, 50, 55, 56]. In the rat, mouse and human, the regulation of the GnRH receptor gene involves PKC/MAPK and the induction of early genes cFos and cJun that interact with activating protein-1 (AP-1) motifs. With regards to the mouse promoter, additional elements that bind octamer binding protein Oct-1 and nuclear factor-Y (NF-Y) are required to ful- fil homologous up-regulation by $\mathrm{GnRH}$ in gonadotrope-derived cell lines [57]. In contrast to the $\mathrm{GnRH}$ receptor, regulation of the rat NOS I gene involves mediation via the cAMP pathway and activation of factors that interact with a bipartite element composed of a cAMP regulatory element (CRE) bound to a CRE Binding (CREB)-related factor and an additional domain situated a few base pairs upstream [36]. 


\subsection{The multigenic influence of GnRH as an integrate mechanism for regulated gonadotropin secretion}

\subsection{1. $\mathrm{LH}$}

As mentioned above, GnRH can induce cFos and cJun that form a heterodimeric complex of transcription factors, which increase the activity of AP-1-possessing promoter genes. Egr-1 (early growth response protein 1) is another transcription factor encoding gene that is rapidly induced by GnRH in the gonadotrophs, and this occurs through PKC/MAPK [58, 59]. Egr-1 is indispensable for the tissue-specific expression of the LH $\beta$ subunit gene in concert with SF-1, Sp1 and the pituitary homeobox 1 Pitx 1 $[60,61]$ and its increased expression enhances LH $\beta$ production. Interestingly, a delayed induction of the Egr-1 co-repressor Nab1 has been described in the clonal murine gonadotrope $\alpha \mathrm{T} 3-1$ cell line under prolonged stimulation with $\mathrm{GnRH}$ that could be responsible for the arrest of LH $\beta$ transcription [59]. Induction of Egr-1 and Nab1 may thus provide an attractive model to account for an initial activation followed by inactivation of the LH $\beta$ gene, and could thus explain the dual regulatory action on this gene of a single stimulator, GnRH.

\subsection{2. $\mathrm{FSH}$}

Compared to $\mathrm{LH} \beta$, the nature of the cis regulatory elements involved in the GnRH activation of the FSH $\beta$ gene is poorly understood. Several AP-1 domains could be involved via PKC $[62,63]$. As illustrated in Figure 2, a time-course study by Burger et al. [14] using as a model the castrated testosterone-treated male rat showed that transcriptional activation of the FSH $\beta$ gene was progressive but high and durable at low GnRH pulse frequencies. However, under a relatively rapid stimulation, it declined after a swift but transient (1.5 h) increase. Since the expression of the FSH $\beta$ gene is also activine-dependent [64] and gonadotrophs express the activin regulator, follista-

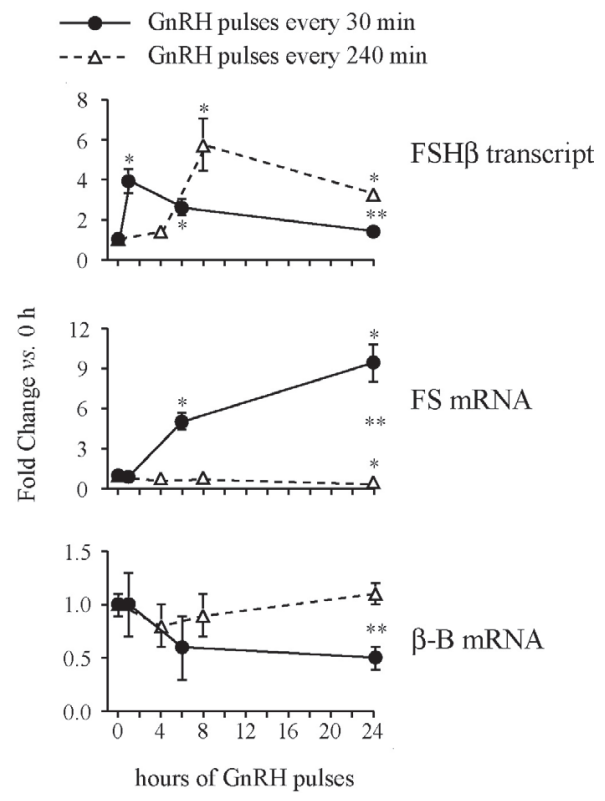

Figure 2. Influence of the GnRH pulse frequency on $\mathrm{FSH} \beta$, follistatin and activin $\beta \mathrm{B}$ gene expression. Castrated, testosterone replaced male rats were $i v$ pulsed with $25 \mathrm{ng}$ GnRH every 30 (fast) and 240 (slow) min for $1-24 \mathrm{~h}(n=4$ 8 rats/observation). Levels of primary $\mathrm{FSH} \beta$ transcript and follistatin (FS) and activin $\beta \mathrm{B}$ mRNA were measured by quantitative RT-PCR using appropriate primers and data are expressed as fold change vs. controls $(0 \mathrm{~h})$. * Significant differences $(P<0.05)$ vs. untreated castratedtestosterone controls $(0 \mathrm{~h})$. ** Significant differences between GnRH pulse regimen at $24 \mathrm{~h}$. From Burger et al. [14], with permission. Copyright 2002, The Endocrine Society.

tin [65], the effects of pulsatile vs. permanent presence of $\mathrm{GnRH}$ on the expression of the follistatin gene were examined. As shown in Figure 2, while GnRH applied at slow frequency was rather inefficient, rapid pulse frequencies increased follistatin mRNA thus supporting the concept of an activin/ follistatin autocrine/paracrine loop [14, 66, 67]. No such effects have been observed on activin $\beta B$ mRNA levels although they significantly decreased after prolonged high frequency stimulation. These data thus could account for the higher expression of the 
FSH $\beta$ gene in response to GnRH at low frequencies as described earlier [13] and suggest that the low FSH $\beta$ expression observed at high frequencies could result from the induction of follistatin working to counteract the stimulatory effects of activin. These actions represent another mechanism, by which the pulsatile profile of GnRH secretion could differentially regulate FSH and LH secretion.

\section{CONCLUSION}

In conclusion, while the functional activity of pituitary gonadotrophs is highly dependent on the GnRH pulse frequency, this property can not rely on the classic homologous desensitisation/endocytic recycling of GPCR receptors. Instead, the GnRH action should be viewed as an interaction of this neurohormone with a strongly atypical receptor lacking the C-terminal tail and thus incapable of rapid desensitisation in contrast to the vast majority of GPCR. Consequently "desensitisation" (estimated through LH and FSH release) does not reflect general cell refractoriness, but rather individual responses limited to a group of genes/proteins, while expecting other typical regulations to be maintained or even amplified. Indeed under a similar paradigm i.e. a given typical GnRH stimulation frequency, some GnRH responsive genes are observed to be activated while others are not (or become inactivated), providing the first arguments in favour of this concept and substantiates a participation of the multigenic action of GnRH in the modulation of its own action. Recent studies have demonstrated that, with the exception of rare primates, mammals exclusively expressed the GnRH receptor type I while in such species the identification of genomic remnant traces of type II GnRH receptor suggested the silencing of this gene during evolution [68]. The acquisition of a single gene encoding a $\mathrm{GnRH}$ receptor deprived of a C-terminal tail, together with the episodic nature of the $\mathrm{GnRH}$ release may represent an evolution- ary adaptation to improve integral neuroendocrine control of reproduction. It is most probable that further studies will allow the identification of some additional alternative strategies in the differential modulation of the gonadotropic secretory function.

\section{REFERENCES}

[1] Conn PM, Crowley. Gonadotropin-releasing hormone and its analogs. Annu Rev Med 1994, 45: 391-405.

[2] Emmons G, Schally AV. The use of luteinizing hormone-releasing hormone agonists and antagonists in gynaecological cancers. Hum Reprod 1994, 9: 1364-1379.

[3] Combarnous Y, Galet C, Crépieux P, Chopineau M, Counis R. Les Gonadotropines: Structures, fonction, mécanismes d'action. In: Thibault C, Levasseur MC (Eds), La Reproduction des Mammifères et de l'Homme, Ellipses, 2001, p 108-121.

[4] Tougard C, Tixier-Vidal A. Lactotropes and gonadotropes. In: Knobil E, Neill JD (Eds), The Physiology of Reproduction, Raven Press, New-York, 1994, p 1711-1747.

[5] Counis R. Gonadotropin biosynthesis. In Neill J, Knobil E (Eds), Encyclopedia of Reproduction, Acad Press, San Diego, 1999, p 507-520.

[6] Mason AJ, Hayflick JS, Zoeller RT, Young III WS, Phillips HS, Nikolics K, Seeburg PH. A deletion truncating the gonadotropin-releasing hormone gene is responsible for hypogonadism in the hpg mouse. Science 1986, 234: 1366-1371.

[7] Legouis R, Hardelin JP, Levilliers J, Claverie JM, Compain S, Wunderle V, Millasseau P, Le Paslier D, Cohen D, Caterina D, Bougueleret L, Delemarre-Van de Waal H, Lutfalla G, Weissenbach J, Petit C. The candidate gene for the X-linked Kallmann syndrome encodes a protein related to adhesion molecules. Cell 1991, 67: 423-435.

[8] Seminara SB, Hayes FJ, Crowley WF Jr. Gonadotropin-releasing hormone deficiency in the human (idiopathic hypogonadotropic hypogonadism and Kallmann's syndrome): pathophysiological and genetic considerations. Endocr Rev 1998, 19: 521-539.

[9] Kottler ML, Counis R, Bouchard P. Mutations of the GnRH receptor gene: a new cause of autosomal-recessive hypogonadotropic hypogonadism. Arch Med Res 1999, 30: 481-485.

[10] Hamernik DL, Crowder ME, Nilson JH, Nett TM. Measurement of messenger ribonucleic acid for luteinizing hormone beta-subunit, 
alpha-subunit, growth hormone, and prolactin after hypothalamic pituitary disconnection in ovariectomized ewes. Endocrinology 1986 , 119: 2704-2710.

[11] Lalloz MRA, Detta A, Clayton RN. Gonadotropin-releasing hormone is required for enhanced luteinizing hormone subunit gene expression in vivo. Endocrinology 1988, 122: 1681-1688.

[12] White RB, Eisen JA, Kasten TL, Fernald RD. Second gene for gonadotropin-releasing hormone in humans. Proc Natl Acad Sci USA 1998, 95: 305-309.

[13] Dalkin AC, Haisenleder DJ, Ortolano GA, Ellis TR, Marshall JC. The frequency of gonadotropin-releasing hormone stimulation differentially regulates gonadotropin subunit messenger ribonucleic acid expression. Endocrinology 1989, 125: 917-924.

[14] Burger LL, Dalkin AC, Aylor KW, Haisenleder DJ, Marshall JC. GnRH pulse frequency modulation of gonadotropin subunit gene transcription in normal gonadotropes Assessment by primary transcript assay provides evidence for roles of $\mathrm{GnRH}$ and follistatin. Endocrinology 2002, 143: 3243-3249.

[15] Lalloz MRA, Detta A, Clayton RN. Gonadotropin-releasing hormone desensitization preferentially inhibits expression of the luteinizing hormone $\beta$-subunit gene in vivo. Endocrinology 1988, 122: 1689-1694.

[16] Rodin DA, Lalloz MRA, Clayton RN. Gonadotropin-releasing hormone regulates follicle-stimulating hormone $\beta$-subunit gene expression in the male rat. Endocrinology 1988, 125: 1282-1289.

[17] Lerrant Y, Kottler ML, Bergametti F, Moumni M, Blumberg-Tick J, Counis R. Expression of gonadotropin-releasing hormone $(\mathrm{GnRH})$ receptor gene is altered by $\mathrm{GnRH}$ agonist desensitization in a manner similar to that of gonadotropin $\beta$-subunit genes in normal and castrated rat pituitary. Endocrinology 1995, 136: 2803-2808.

[18] Lahlou N, Roger M, Chaussain J, Feinstein M, Sultan C, Toublanc JE, Schally AV, Scholler R. Gonadotropin and alpha-subunit secretion during long-term suppression by D-Trp ${ }^{6}$ luteinizing hormone releasing hormone microcapsules as treatment of precocious puberty. J Clin Endocrinol Metab 1987, 65: 946-953.

[19] Andrews WV, Staley DD, Huckel WR, Conn PM. Stimulation of luteinizing hormone (LH) release and phospholipid breakdown by guanosine triphosphate in permeabilized pituitary gonadotropes: antagonist action suggests association of a $\mathrm{G}$ protein and gonadotropinreleasing hormone receptor. Endocrinology 1986, 119: 2537-2546.
[20] Millar RP, Lu ZL, Pawson AJ, Flanagan CA, Morgan K, Maudsley SR. Gonadotropinreleasing hormone receptors. Endocr Rev 2004, 25: 235-275.

[21] Ferguson SS, Barak LS, Zhang J, Caron MG. $\mathrm{G}$ protein-coupled receptor regulation: role of $\mathrm{G}$ protein-coupled receptor kinases and arrestins. Can J Physiol Pharmacol 1996, 74: 1095-1010.

[22] Lefkowitz RJ. G protein-coupled receptors. III. New roles for receptor kinases and $\beta$ arrestins in receptor signaling and desensitization. J Biol Chem 1998, 273: 18677-18680.

[23] Lethimonier C, Madigou T, Munoz-Cueto JA, Lareyre JJ, Kah O. Evolutionary aspects of GnRHs, GnRH neuronal systems and GnRH receptors in teleost fish. Gen Comp Endocrinol 2004, 135: 1-16.

[24] Davidson JS, Wakefield IK, Millar RP. Absence of rapid desensitization of the mouse gonadotropin-releasing hormone receptor. Biochem J 1994, 300: 299-302.

[25] Pawson AJ, Katz A, Sun YM, Lopes J, Illing N, Millar RP, Davidson JS. Contrasting internalization kinetics of human and chicken gonadotropin-releasing hormone receptors mediated by $\mathrm{C}$-terminal tail. J Endocrinol 1998, 156: R9-R12.

[26] McArdle CA, Franklin J, Green L, Hislop JN. Signalling, cycling and desensitisation of gonadotropin-releasing hormone receptors. J Endocrinol 2002, 173: 1-11.

[27] Stojilkovic S, Reinhardt J, Catt KJ. Gonadotropin-releasing hormone receptors: structure and signal transduction pathways. Endocr Rev 1994, 15: 462-499.

[28] Naor Z, Benard O, Seger R. Activation of MAPK cascades by $G$ protein-coupled_receptors: the case of gonadotropin-releasing hormone. Trends Endocrinol Metab 2000, 11: 91-99.

[29] Sundaresan S, Colin IM, Pestell RG, Jameson JL. Stimulation of mitogen-activated protein kinase by gonadotropin-releasing hormone: evidence for the involvement of protein kinase C. Endocrinology 1996, 137: 304-311.

[30] Ceccattelli S, Hulting AL, Zhang X, Gustafsson L, Villar M, Hökfelt T. Nitric oxide synthase in the rat anterior pituitary gland and the role of nitric oxide in regulation of luteinizing hormone secretion. Proc Natl Acad Sci USA 1993, 90: 11292-11296.

[31] Lozach A, Garrel G, Lerrant Y, Bérault A, Counis R. GnRH-dependent up-regulation of nitric oxide synthase I level in pituitary gonadotrophs mediates cGMP elevation during rat proestrus. Mol Cell Endocrinol 1998, 143: 43-51. 
[32] Starzec A, Jutisz M, Counis R. Cyclic adenosine monophosphate and phorbol ester, like gonadotropin-releasing hormone, stimulate the biosynthesis of luteinizing hormone polypeptide chains in a nonadditive manner. Mol Endocrinol 1989, 3: 618-624.

[33] Horton CD, Halvorson LM. The cAMP signaling system regulates $\mathrm{LH} \beta$ gene expression: roles of early growth response protein-1, SP1 and steroidogenic factor-1. J Mol Endocrinol 2004, 32: 291-306.

[34] Pincas H, Laverrière JN, Counis R. Pituitary adenylate cyclase-activating polypeptide and cyclic adenosine 3', 5'-monophosphate stimulate the promoter activity of the rat $\mathrm{GnRH}$ receptor gene via a bipartite response element in gonadotrope-derived cells. J Biol Chem 2001, 276: 23562-23571

[35] Garrel G, Lozach A, Bachir LK, Laverrière JN, Counis R. Pituitary adenylate cyclaseactivating polypeptide stimulates nitric oxide synthase type I expression and potentiates the cGMP response to gonadotropin-releasing hormone of rat pituitary gonadotrophs. J Biol Chem 2002, 277: 46391-46401.

[36] Bachir LK, Garrel G, Lozach A, Laverrière JN, Counis R. The rat pituitary promoter of the neuronal nitric oxide synthase gene contains an Sp1-, LIM homeodomain-dependent enhancer and a distinct bipartite gonadotropin-releasing hormone-responsive region. Endocrinology 2003, 144: 3995-4007.

[37] Junoy B, Maccario H, Mas JL, Enjalbert A, Drouva S. Proteasome implication in phorbol ester- and GnRH-induced selective down-regulation of PKC $(\alpha, \varepsilon, \zeta)$ in $\alpha \mathrm{T} 3-1$ and L $\beta \mathrm{T} 2$ gonadotrope cell lines. Endocrinology 2002, 143: 1386-1403.

[38] Wojcikiewicz RJ, Xu Q, Webster JM, Alzayady $\mathrm{K}$, Gao C. Ubiquitination and proteasomal degradation of endogenous and exogenous inositol 1,4,5-trisphosphate receptors in alpha T3-1 anterior pituitary cells. J Biol Chem 2003, 278: 940-947.

[39] Kakar SS, Winters SJ, Zacharias W, Miller DM, Flynn S. Identification of distinct gene expression profiles associated with treatment of LbetaT2 cells with gonadotropin-releasing hormone agonist using microarray analysis. Gene 2003, 308: 67-77.

[40] Yasin M, Dalkin AC, Haisenleder DJ, Kerrigan JR, Marshall JC. Gonadotropin-releasing hormone $(\mathrm{GnRH})$ pulse pattern regulates $\mathrm{GnRH}$ receptor gene expression: augmentation by estradiol. Endocrinology 1995, 136: 15591564.

[41] Garrel G, Lerrant Y, Siriostis C, Bérault A, Magre S, Bouchaud C, Counis R. Evidence that gonadotropin-releasing hormone stimulates gene expression and levels of active nitric oxide synthase type I in pituitary gonadotrophs, a process altered by desensitization and, indirectly, by gonadal steroids. Endocrinology 1998, 139: 2163-2170.

[42] Garrel G, Lerrant Y, Ribot G, Counis R. Messenger ribonucleic acids for $\alpha$ and $\beta$ isoforms of cyclic adenosine 3',5'-monophosphatedependent protein kinase subunits present in the anterior pituitary. Regulation of RII $\beta$ and $\mathrm{C} \alpha$ gene expression by the cyclic nucleotide and phorbol ester. Endocrinology 1993, 133: 1010-1019.

[43] Harris D, Reiss N, Naor Z. Differential activation of protein kinase $C \delta$ and $\varepsilon$ gene expression by gonadotropin-releasing hormone in $\alpha \mathrm{T} 3-1$ cells. Autoregulation by protein kinase C. J Biol Chem 1997, 272: 13534-13540.

[44] Clayton RN, Catt KJ. Gonadotropin-releasing hormone receptors: characterization, physiological regulation, and relationship to reproductive function. Endocr Rev 1981, 2: 186209.

[45] Bauer-Dantoin AC, Hollenberg AN, Jameson JL. Dynamic regulation of gonadotropinreleasing hormone receptor mRNA levels in the anterior pituitary gland during the rat estrous cycle. Endocrinology 1993, 133: 1911-1914.

[46] Albarracin CT, Kaiser UB, Chin WW. Isolation and characterization of the 5'-flanking region of the mouse gonadotropin-releasing hormone receptor gene. Endocrinology 1994, 135: 2300-2306.

[47] Norwitz ER, Cardona GR, Jeong KH, Chin WW. Identification and characterization of the gonadotropin-releasing hormone response elements in the mouse gonadotropin-releasing hormone receptor gene. J Biol Chem 1999, 274: 867-880.

[48] Pincas H, Forraï Z, Chauvin S, Laverrière JN, Counis R. Multiple elements in the distal part of the $1.2 \mathrm{~kb} \mathrm{5}$ '-flanking region of the rat $\mathrm{GnRH}$ receptor gene regulate gonadotropespecific expression conferred by proximal domain. Mol Cell Endocrinol 1998, 144: 95108 .

[49] Pincas H, Amoyel K, Counis R, Laverrière JN. Proximal cis-acting elements, including steroidogenic factor 1 , mediate the efficiency of a distal enhancer in the promoter of the rat gonadotropin-releasing hormone receptor gene. Mol Endocrinol 2001, 15: 319-337.

[50] Bachir LK, Laverrière JN, Counis R. Isolation and characterization of a rat nitric oxide synthase type I gene promoter which confers expression and regulation in pituitary gonadotrope cells. Endocrinology 2001, 142: 46314642 . 
[51] Wei X, Sasaki M, Huang H, Dawson VL, Dawson TM. The orphan nuclear receptor, steroidogenic factor 1 , regulates neuronal nitric oxide synthase gene expression in pituitary gonadotropes. Mol Endocrinol 16: 2828-2839.

[52] Granger A, Ngô-Muller V, Bleux C, Guigon C, Pincas H, Magre S, Daegelen D, TixierVidal $\mathrm{A}$, Counis R, Laverrière JN. The promoter of the rat gonadotropin-releasing hormone receptor gene directs the expression of the human placental alkaline phosphatase reporter gene in gonadotrope cells in the anterior pituitary gland as well as in multiple extrapituitary tissues. Endocrinology 2004, 145: 983-993.

[53] McCue JM, Quirk CC, Nelson SE, Bowen RA, Clay CM. Expression of a murine gonadotropin-releasing hormone receptor luciferase fusion gene in transgenic mice is diminished by immunoneutralization of gonadotropinreleasing hormone. Endocrinology 1997, 138: 3154-3160.

[54] Duval DL, Farris AR, Quirk CC, Nett TM, Hamernik DL, Clay CM. Responsiveness of the ovine gonadotropin-releasing hormone receptor gene to estradiol and gonadotropinreleasing hormone is not detectable in vitro but is revealed in transgenic mice. Endocrinology 2000, 141: 1001-1010.

[55] Norwitz ER, Xu S, Xu J, Spiryda LB, Park JS, Jeong KH, McGee EA, Kaiser UB. Direct binding of AP-1 (Fos/Jun) proteins to a SMAD binding element facilitates both gonadotropin-releasing hormone (GnRH)- and activin-mediated transcriptional activation of the mouse GnRH receptor gene. J Biol Chem 2002, 277: 37469-37478.

[56] White BR, Duval DL, Mulvaney JM, Roberson MS, Clay CM. Homologous regulation of the gonadotropin-releasing hormone receptor gene is partially mediated by protein kinase $C$ activation of an activator protein-1 element. Mol Endocrinol 1999, 13: 566-577.

[57] Kam KY, Jeong KH, Norwitz ER, Jorgensen EM, Kaiser UB. Oct-1 and Nuclear factor Y bind to the SURG-1 element to direct basal and gonadotropin-releasing hormone ( $\mathrm{GnRH})$ stimulated mouse GnRH receptor gene transcription. Mol Endocrinol 2005, 19: 148-162.

[58] Halvorson LM, Ito M, Jameson JL, Chin WW. Steroidogenic factor-1 and early growth response protein 1 act through two composite DNA binding sites to regulate luteinizing hormone $\beta$-subunit gene expression. J Biol Chem 1998, 273: 14712-14720.

[59] Wolfe MW, Call GB. Early growth response protein 1 binds to the luteinizing hormone- $\beta$ promoter and mediates gonadotropin-releas- ing hormone-stimulated gene expression. Mol Endocrinol 1999, 13: 752-763.

[60] Kaiser UB, Halvorson LM, Chen MT. Sp1, steroidogenic factor 1 (SF-1), and early growth response protein 1 (Egr-1) binding sites form a tripartite gonadotropin-releasing hormone response element in the rat luteinizing hormone- $\beta$ gene promoter: an integral role for SF-1. Mol Endocrinol 2000, 14: 12351245.

[61] Topilko P, Schneider-Maunoury S, Levi G, Trembleau A, Gourdji D, Driancourt MA, Rao CV, Charnay P. Multiple pituitary and ovarian defects in Krox-24 (NGFI-A, Egr-1)targetted mice. Mol Endocrinol 1998, 12: 107-122.

[62] Huang HJ, Sebastian J, Strahl BD, Wu JC, Miller WL. The promoter for the ovine follicle-stimulating hormone- $\beta$ gene $(\mathrm{FSH} \beta)$ confers FSH $\beta$-like expression on luciferase in transgenic mice: regulatory studies in vivo and in vitro. Endocrinology 2001, 142: 22602266.

[63] Coss D, Jacobs SB, Bender CE, Mellon. A novel AP-1 site is critical for maximal induction of the follicle-stimulating hormone beta gene by gonadotropin-releasing hormone. J Biol Chem 2004, 279: 152-162.

[64] Weiss J, Guendner MJ, Halvorson LM, Jameson JL. Transcriptional activation of the follicle-stimulating hormone beta-subunit gene by activin. Endocrinology 1995, 136: 1885-1891.

[65] Kaiser UB, Lee BL, Caroll RS, Unabia G, Chin WW, Childs GV. Follistatin gene expression in the pituitary: localization in gonadotrophs and folliculostellate cells in diestrus rats. Endocrinology 1992, 130: 30483056.

[66] Besecke LM, Guendner MJ, Schneyer AL, Bauer DA, Jameson JL, Weiss J. Gonadotropin-releasing hormone regulates folliclestimulating hormone-beta gene expression through an activin/follistatin autocrine or paracrine loop. Endocrinology 1996, 137: 3667-3673.

[67] Dalkin AC, Haisenleder DJ, Gilrain JT, Aylor K, Yasin M, Marshall JC. Gonadotropinreleasing hormone regulation of gonadotropin subunit gene expression in female rats: actions on follicle-stimulating hormone beta messenger ribonucleic acid (mRNA) involve differential expression of pituitary activin (beta-B) and follistatin mRNAs. Endocrinology 1999, 140: 903-908.

[68] Pawson AJ, Morgan K, Maudsley SR, Millar RP. Type II gonadotropin-releasing hormone (GnRH II) in reproductive biology. Reproduction 2003, 126: 271-278. 